\title{
The Applicability of Ijarah Al- Mawsufah Fi Al-Dhimmah in Malaysia
}

\author{
Mouhamadou Moctar Dieng, \\ International Islamic University Malaysia
}

\begin{abstract}
Purchasing a house under construction is definitely a risky investment for both homebuyer and financier. An Ijarah mawsufah fi al-dhimmah (forward lease) is a method of leasing where the lessor accepts rent prior to the delivery of an asset or property. The rental paid is refunded if the asset is not delivered. This paper aims to examine the legality of forward lease and its applicability in Malaysia. Based on a review of scholarly papers and secondary data collected from company websites, this paper concludes that the benefits of using Ijarah mawsufah fi al-dhimmah are not fully exercised and more efforts need to be done in order to benefit all key stakeholders.
\end{abstract}

Keywords: Ijarah Mawsufah Fi Al-Dhimmah; Forward Lease; Legal Documentation; Home Financing; Project Financing; Abandoned Housing Project; Property Under Construction 


\section{Background of the Study}

The financial crisis of 2007-2008 led many to recognise the damage caused by "abusive mortgage practices" (Neate, 2016) and the importance of ethical banking. The principles of Shariah (Islamic law) provide a comprehensive ethical framework and guidelines governing business conduct and financial activities. For Muslims, it is particularly important to use products or services that not only comply with Shariah principles but are also toyyiban (good).

Ijarah (lease) is a commonly used finance instrument for long-term capital intensive projects such as infrastructure, transportation and energy plants (World Bank, 2017). Forward Ijarah (Ijarah mawsufah fi al-dhimmah) is a lease agreement which involves leasing properties under construction. The key advantage of using forward Ijarah is that the financier (lessor) is able to receive advance rental during the construction phase (Global Islamic Finance Report, 2016) while retaining legal ownership of the property until the end of the lease term. Upon completion of the construction phase, the lessee may purchase the leased property and the advance rental amount may be treated as part of selling price; if the property cannot be delivered on time, the rental received by the financier shall be refunded to the lessee (Bank Negara Malaysia, 2009: 7).

Notwithstanding its benefits, forward Ijarah has received little attention in the literature discussing the use of Islamic mortgages and project financing. Given the economic role played by financial institutions in causing the financial crisis in 20072008 , it is worthwhile to examine a mode of home financing which benefits all stakeholders. Forward Ijarah appears to fit these criteria. Therefore, this paper aims to explore the applicability of forward Ijarah in financing housing projects in Malaysia.

In the next section, an overview of the Malaysian housing market and a literature review of Islamic home financing are presented, followed by a case example of forward Ijarah. The main findings are then summarised.

\section{The Housing Market in Malaysia}

Over the past few years, Malaysia has been facing an oversupply of new properties. Across the country, there is a sharp increase of $200 \%$ in unsold residential units between the years 2014 and 2018 (Quah, 2019). This decline in property sales inevitably places financial pressure on property developers. Additionally, they face credit restrictions imposed by the government (Hui, 2011) and tighter lending policies from banks (Quah, 2019).

However, a closer look at the numbers reveals that these unsold units are not affordable for the masses. Yap and Ng (2018) report that the purchasing power of homebuyers in Malaysia is low due to the mismatch between house price and income level in Malaysia. Soaring house prices have been driven by speculative demand and supply (National Housing Department Malaysia, 2001). Furthermore, it may be in the interest of developers and speculators to purchase land with no intention to build housing as land prices continue to rise.

International Journal of Management and Applied Research, 2019, Vol. 6, No. 4 
Policy attention has also been devoted to addressing the housing problem; exemption from stamp duty for property valued at under RM1 million and incentives for firsttime buyer (Quah, 2019). One can argue that these measures can at best tackle the symptoms but not the causes.

In addition to the oversupply of unaffordable housing, the Malaysian property market has another problem; abandoned housing projects. Data from the Ministry of Urban Well-being, Housing and Local Government show that there were a total of 253 abandoned private housing projects involving more than 20,640 homebuyers between 2009 and 2017 (The Sun Daily, 2017). In the event of the developer abandoning the housing project, homebuyers are left with an unfinished house and on top of that, they are obliged by the banks to continue pay mortgage payments (Kashi and Mohamad, 2017). There is a legal and statutory gap in the event of project abandonment; the interests of the homebuyers are not protected by the law. This highlights the need for more robust financial consumer protection measures for homebuyers.

More innovative housing solutions are needed to address the housing problem in Malaysia. While there are many approaches to solving the housing problem in Malaysia, ranging from tax relief to law reform, this paper focuses only on financing property under construction using forward Ijarah. Theoretically, forward Ijarah allows homebuyers to buy property on fair terms. The underlying concepts of Ijarah and forward Ijarah are presented in the next section.

\section{Islamic Home Financing in Malaysia}

Home to a growing Islamic banking and finance industry, Malaysia has one of the most sophisticated Islamic financial markets in the world. However, the Islamic mortgage sector has received criticism from academia (Amin et al., 2016; Kashi and Mohamad, 2017; Wei and Thaker, 2017) and some mortgage holders filed legal cases against the Islamic mortgage providers.

Under Shariah (Islamic law), an interest-based loan is not permissible because the practise of earning interest (riba) is considered to be exploitative of the borrower. Islamic banks offer interest-free home financing products in accordance with Islamic law. Besides the prohibition of riba, another key difference between Islamic and conventional finance is that there is no penalty for late payment. The prohibition of gharar (uncertainty) is of equal importance under Islamic law. Financial practices such as speculation and derivative contracts are not permissible due to the uncertainty involved in these financial arrangements. Forward Ijarah and Istisna are exceptions to gharar, which will be discussed next.

Below is a summary of permissible financing arrangements used for home financing in Malaysia:

\section{Bay Bithaman Ajil (BBA)}

BBA is a type of debt-based contract with deferred payment paid by instalments, the price is determined upfront. However, this type of financing has been heavily

International Journal of Management and Applied Research, 2019, Vol. 6, No. 4 
criticised (Amin et al., 2016; Kashi and Mohamad, 2017; Wei and Thaker, 2017) and been subject to legal disputes over the years. In particular, legal cases such as Bank Islam Malaysia Berhad v Adnan Omar [1994] and Malaysian Banking Bhd v Ho Siok Lin [2006] initiated a continuing debate about the validity and legality of BBA for home financing. Critics argue that BBA is equivalent to a mortgage loan offered by conventional banks due to the formula to calculate the periodic instalments (Kashi and Mohamad, 2017) and the use of a market interest rate (Wei and Thaker, 2017) which is identical to the practices of conventional banks. This goes against the Islamic principle of interest-free loans. Additionally, BBA holders are subject to penalties for late payment or default which is, again, goes against Islamic principles (Kashi and Mohamad, 2017).

\section{Musharakah Mutanaqisah (MM)}

Based on a profit-loss sharing principle, Musharakah Mutanaqisah (MM) is a joint partnership between the Islamic bank and the homebuyer; ownership is shared between the partners at an agreed ratio. Unlike a conventional mortgage, MM relies on rental rates rather than interest rates for the rate of return (Kashi and Mohamad, 2017). Subky et al. (2017) reported that the use of rental rates in MM is subject to many variables such as different local rental rates and market fluctuations. However, MM has also been criticised by scholars due to its unfair ownership transfer rate (Kashi and Mohamad, 2017) and dependence on using benchmarks set by the conventional banks (Wei and Thaker, 2017). In the event of project abandonment by the developer, the procedure used by Islamic banks is against the Islamic principle of profit-loss sharing because the mortgage holder is obliged to acquire the bank's share at the buyout amount (Kashi and Mohamad, 2017: 743).

\section{Istisna}

Istisna is a contract whereby manufacturers (or builders) produce (construct) and deliver the goods (property) in the future. This type of contract can be used for construction and infrastructure projects, especially in Public-Private Partnerships (World Bank, 2017). Under Istisna, payment can be made in a lump sum or in stages (Hasmawati and Mohamad, 2019). The financier is not liable for cost overruns; if the properties are not delivered on time or do not conform to pre-agreed specifications, the borrower is required to pay liquidated damages to the financier (World Bank, 2017). In a study of why Islamic financial institutions (IFIs) are reluctant to adopt Istisna in Malaysia, Hasmawati and Mohamad (2019) concluded the following; first, a construction project has high levels of uncertainty and risk which may affect completion time and quality; second, other instruments such as BBA and MM are easier to implement than Istisna. In other words, Malaysian IFIs consider financing construction projects to be a risky investment. This suggests that an Islamic bank is more risk-averse than its conventional counterpart.

\section{Ijarah}

Ijarah is a lease contract, whereby the lessor (a bank) buys and leases out a property for a rental fee. There several types of Ijarah contract. Under Ijarah wa-iqtina (also known as al-ijarah muntahia bitamleek), the lessor will sell the property to the lessee at the end of the lease term, at an agreed price (Bank Negara Malaysia, 2009). In practice, however, ijarah is not widely used in Malaysian Islamic banks because it not

International Journal of Management and Applied Research, 2019, Vol. 6, No. 4 
only entails a higher capital holding but also an additional tax burden for the bank compared to other modes of financing (Ariff and Rosly, 2011). Mainly, this is because Islamic banks in Malaysia are governed by English Law as well and thus any hire purchase agreement is subject to the Hire Purchase Act 1967 which was designed for conventional leasing. The bank does not hold ownership of the asset or property, which is not in line with the concept of Ijarah (Ariff and Rosly, 2011).

\section{Forward Ijarah}

Ijarah mawsufah fi al-dhimmah (forward Ijarah) is a lease contract under which a bank leases out a property under construction and the lessee is required to pay rent during the construction period and also upon completion of the home (Bank Negara Malaysia, 2009). Forward Ijarah can be used as a standalone contract (Monawer and Aziz, 2015) or combined with other contracts such as Musharakah Mutanaqisah (MM) and Istisna contracts (Bank Negara Malaysia, 2009). Forward Ijarah is suitable for property developers and builders. The Istisn-Ijarah and Wakalah-Ijarah structures are commonly used financial arrangements in the Islamic project finance market (Global Islamic Fiance Report, 2016). These structures allow IFIs to receive repayment from the borrower and achieve the similar margins, liquidity and cash flows to conventional financiers.

Very few studies investigate the concept and use of forward Ijarah in Malaysia. Monawer and Aziz (2015) analysed the juristic views regarding the legality of forward Ijarah and concluded that the use of forward Ijarah has been limited due to dispute among scholars about its legality under Islamic law. The authors found that contemporary scholars did not discuss classical literature thoroughly and this led to disagreement among Muslim scholars. It is therefore likely that IFIs rarely use forward Ijarah to avoid confusion.

The table below summarises the main features of the different home financing products and the controversies around these options.

Table 1: key characteristics and issues of Islamic home financing in Malaysia

\begin{tabular}{|c|c|c|}
\hline & Types of contract & Issues \\
\hline $\begin{array}{l}\text { Bay Bithaman } \\
\text { Ajil (BBA) }\end{array}$ & Deferred payment sale & $\begin{array}{l}\text { 1) Use market interest rate and formula in } \\
\text { computing periodic instalment } \\
\text { 2) Penalty in the event of default and early } \\
\text { redemption }\end{array}$ \\
\hline $\begin{array}{l}\text { Musharakah } \\
\text { Mutanaqisah } \\
\text { (MM) }\end{array}$ & $\begin{array}{l}\text { Profit-loss sharing } \\
\text { partnership }\end{array}$ & $\begin{array}{l}\text { 1) Use benchmark set by conventional bank } \\
\text { 2) Unfair ownership transfer rate } \\
\text { 3) Questionable banking procedure in the } \\
\text { event of project abandonment }\end{array}$ \\
\hline Istisna & Forward sale & $\begin{array}{l}\text { 1) High level of uncertainty and risk } \\
\text { 2) Not favoured by IFIs }\end{array}$ \\
\hline Ijarah & Lease & $\begin{array}{l}\text { 1) High cost } \\
\text { 2) High risk }\end{array}$ \\
\hline Forward Ijarah & Forward lease & Disagreement among scholars \\
\hline
\end{tabular}

International Journal of Management and Applied Research, 2019, Vol. 6, No. 4 
As shown in Table 1, these home financing options are theoretically sound; in practice, however, they are not implemented in accordance with Islamic law. This situation can be explained by the idea that Islamic banking has reached a point which favours shareholder interests. In particular, debt-based financing such as BBA allows Islamic commercial bank to earn competitive returns without taking proportionate risk (Zabri and Haron, 2019). Moreover, these home financing contracts remain controversial due to the use of mainstream banking practices such as taking into account the time value of money. As (Ariff and Rosly, 2011: 317) put it: "There is certainly a need to devise modern financial instruments that will conform fully to the Shariah".

\subsection{Legal Documentation}

Contracts in Malaysia are governed by common law and the Contracts Act 1950; the parties to the contract should ensure that all essential terms are clearly defined and included in the contract, namely liability clauses and contract termination.

The legal documentation used for Islamic home financing is not standardised; more specifically, not only do the terms and conditions for each product differ from one bank to another (Yusoff and Oseni, 2019), but the list of legal documents also varies (Subky et al., 2017). Such noticeable variations may result from different views in the Shariah Committee of each bank, in addition to the financial need to offer competitive financial products to attract customers (Yusoff and Oseni, 2019). According to Subky et al. (2017), such differences can also be partially explained by the form of the bank (i.e. full-fledged Islamic bank, or Islamic subsidiaries of conventional financial institutions). For example, a full-fledged Islamic bank has considerably more documentation than other Islamic Financial Institutions (IFIs) for its MM contract (Asian Institute of Finance, 2013). This bundle of mandatory documents adds additional documentation fees to the homebuyer's costs (Subky et al., 2017) and potentially leads to contractual inconsistencies if not properly cross-referenced (Yusoff and Oseni, 2019).

\subsubsection{Sale and Purchase Agreement}

Sale and Purchase Agreement (SPA) is a contract which embodies detailed terms and conditions in property transactions, including an agreed purchase price, the type of financing, the time of delivery of the vacant possession of the property, etc. Typically, the SPA would include clauses to regulate premature termination such as penalties and forfeiture of deposits. SPA forms part of the full set of legal documentation for a mortgage, including Islamic home financing (Yusoff and Oseni, 2019).

Some of the wording used in the SPA is "distorting the value of Islamic finance" somewhat (Yusoff and Oseni, 2019: 460) by the use of penalties and interest-bearing repayments included in the SPA. Under Islamic law, the prohibition of riba means that the Islamic financier cannot charge an additional amount (e.g. interest) in the event of late payment or default. This begs the question "whether such [legal] documentation serves the original value proposition of Islamic law" (Yusoff and Oseni, 2019: 458).

Yusoff and Oseni (2019) highlights the importance of incorporating Shariah principles in drafting legal documentation since Islamic banks take additional risks in

International Journal of Management and Applied Research, 2019, Vol. 6, No. 4 
ownership transfer compared to conventional banking practices. For example, to purchase a house using BBA, the Islamic bank purchases a property and resell it to a homebuyer; however, there is "no real ownership transfer" in such purchases (Kashi and Mohamad, 2017: 741) because they "represent sale without any true sale attributes" (Ariff and Rosly, 2011: 306). This example not only shows SPA to be contradictory to the objectives of BBA but also indicates a need to devise a Shariahcompliant SPA.

\section{Legality of Forward Ijarah}

In examining the legality of forward Ijarah, it is best to start with the authoritative bodies in Islamic finance; the Shariah Advisory Council and the central bank of Malaysia (Bank Negara Malaysia).

According to the Shariah Advisory Council (2010: 17), "Ijarah Mawsufah fi alDhimmah is permissible based on qiyas to Salam contract". Shariah Advisory Council also clarified that, forward Ijarah differs from Salam contracts in that advanced payment is not a requirement for forward Ijarah.

Below are brief extracts from the Draft of Shariah Parameter Reference 2: Ijarah Contract, published by Bank Negara Malaysia (2009: 6-7).

Payment: The rental payment can be made in full or in stages according to agreed terms; the exact timing and amount of payments must be determined when the contract is finalised.

Time of delivery: The property or asset must be delivered on a future agreed date.

In the event of default: The lessee can receive a refund if the asset cannot be delivered on time and of good quality.

Procurement: Upon completion of the construction, the lessee has the right to purchase the leased asset and the rental amount may be taken as part of the selling price.

However, as pointed out by Monawer and Aziz (2015), both Bank Negara Malaysia and Shariah Advisory Council did not address matters related to project abandonment; who will be liable for liquidated damages? Do lessees need to pay rental payment even if the asset will never be delivered? Can the lessee get a refund if the developer abandons the project?

\subsection{Classical Islamic Jurisprudential Views}

The scholarly views regarding forward Ijarah are varied. Four traditional Sunni Islamic schools of jurisprudence; Hanafi, Maliki, Syafii and Hanbali, have different views with respect to the wording of forward Ijarah. In particular, should forward Ijarah be treated as a forward contract or leasing agreement?

International Journal of Management and Applied Research, 2019, Vol. 6, No. 4 
Opinion regarding the wording of forward Ijarah is divided. Like a forward contract, forward Ijarah involves the sale of an asset that has not yet been produced at the time of signing the contract. Scholars from the Maliki, Syafii and Hanbali schools consider that it is permissible to lease assets that are still under construction and consider forward leasing as an exception to the prohibition of gharar. The Hanafi scholars, on the other hand, did not explicitly confirm the legality of Ijarah but rather discussed the legality of Ijarah in general and introduced different forms of Ijarah, one of them being forward Ijarah (Monawer and Aziz, 2015). Contemporary scholars (Abu Ghuddah, 2007; Lahsasna, 2018) mention that the Hanafi School did not allow forward Ijarah based on the notion that Hanafi only recognises property which has tangible attributes or substance and for that reason forward Ijarah is null because it involves property under construction that does not yet exist. But this view is not completely true, according to Monawer and Aziz (2015). Referring to classical texts from multiple Hanafi scholars, Monawer and Aziz (2015) argue that Hanafi scholars supported the concept of forward Ijarah. Monawer and Aziz (2015) also suggest that Hanafi scholars allowed forward Ijarah on the basis of istihsan (juristic preference), a subsidiary source of Islamic law.

In addition, there is no consensus among Muslim Schools regarding the payment occurred in forward Ijarah. The Maliki and Syafii Schools insist that spot payments must be made in forward Ijarah, while the Hanbali scholars held the contrary view (Lahsasna, 2018). The debate whether the payment should be made upfront or delayed is based on the divided views regarding the nature of a forward contract in the context of Islamic finance. Salam is a permissible forward contract where the Islamic financer pays the full payment in advance when buying commodities (e.g. agricultural products) that will be delivered at a future date. Hanafi scholars appear to be flexible in this matter (Monawer and Aziz, 2015), while Hanbali scholars concluded that payment can be made at later stage as long as the terms "Salam", "Salf", and "Saraf" are avoided in forward Ijarah contracts (Lahsasna, 2018). Different interpretations of Shariah rules certainly add barriers to Islamic financial institutions ability to include forward Ijarah in their portfolio.

\section{Case Example: Kuwait Finance House}

Kuwait Finance House was established in the State of Kuwait in 1977 and its subsidiary -- Kuwait Finance House Malaysia Berhad (KFHMB) became a fullyfledged Islamic bank in Malaysia in 2005. Its financial products include corporate banking and personal banking. This article solely focuses on forward Ijarah offered by KFHMB.

\subsection{Key Features}

According to the product disclosure sheet published in 2019, KFHMB offers forward Ijarah for individuals and businesses to finance property under construction, including both residential and commercial properties. During the construction period, the lessee (customer) pays monthly rental payments to KFHMB. At the end of the leasing period, the ownership will be transferred to the customer by sale, another financial arrangement.

International Journal of Management and Applied Research, 2019, Vol. 6, No. 4 
Depending on the type of property, the customer has to pay a deposit of no more than $20 \%$ of the property's value (Open Market Value or selling price provided by the property developer). The customer has the option to pay monthly rental payments either at a fixed or variable rate.

Another important component of forward Ijarah provided by KFHMB is that the customer has the option to be covered under the Takaful (Islamic insurance) offered by the bank.

The product disclosure sheet also details likely actions to be taken by KFHMB if the customer is unable to fulfil their obligations which include the following; taking legal action, reporting to the local credit bureau, imposing charges for late payment and a revised financial rate resulting in higher instalment payments.

\subsection{Legal Documentation}

The documentation required for this product is extensive and complex. The following documents are required to form the totality of the legal documentation required: 1) Asset Purchase Agreement, 2) Memorandum of Transfer, 3) Ijarah Agreement, 4) Guarantee Agreement Charge Document, 5) Deed of Assignment and 6) Letter of Offer/Acceptance.

\subsection{Major Risks}

The customer may need to pay a higher (than expected) rental amount due to floating rate. The monthly rental amount varies due to fluctuations of the Base Rate declared by KFHMB. The rental amount will be revised concurrently if the declared rate is higher than before. The rental payment is capped at $12 \%$ and the minimum rate is $4 \%$.

In the event of project abandonment, the lessee is obliged to pay liquidated damages to KFHMB. In this regard, the benefit of having a refund in the event of project abandonment, which is imperative to forward Ijarah, is lost. The lessee not only suffers loss of rental payments and deposit, but is also liable for liquated damages. This places huge risk on ordinary homebuyers who have no control over the completion of the construction project.

\subsection{Contract Ambiguity}

The information regarding forward Ijarah offered by KFHMB was collected from its official website, without any attempt to collect primary data from the personnel who work in KFHMB. With little information at hand, the authors of this paper have the following questions regarding this product:

First, the lessees have an option of cover through Islamic insurance. However, little is known about the cover; does it cover project abandonment and property loss in case of fire and flood?

Second, KFHMB has not mentioned the computation of the purchase price. Is the monthly rental payment treated as part of the purchase price?

International Journal of Management and Applied Research, 2019, Vol. 6, No. 4 
Third, KFHMB does not mention the type of sale contract (e.g. al-bay, Ijarah waiqtina, Murabahah, etc) to be used once the construction phase is ended. It is also not clear whether the customer is obliged to purchase the leased property. Can the customer choose not to purchase the property? Does it consider this as early termination?

\section{Conclusion}

Purchasing a house under construction is definitely a risky investment for both homebuyer and bank. Serious cost overrun is likely to affect project cash flow and ultimately may lead to project abandonment. In circumstances where the property developer abandons the housing project, homebuyers not only lose their deposit but are also obliged to pay mortgage payments. Theoretically, forward Ijarah offers peace of mind to the lessee (the homebuyer) in the case of project abandonment because "the rental amount received by financier shall be refunded to the lessee if the asset cannot be effectively delivered to the lessee for the agreed period" (Bank Negara Malaysia, 2009: 7).

This paper explored the applicability of forward Ijarah in home financing in Malaysia and concluded that there is a gap between theory and practice in Islamic banking. Using Kuwait Finance House Malaysia Berhad (KFHMB) as a case example, this study showed that the benefits of forward Ijarah are not fully exercised in the current offering. Based on the information given in its product disclosure sheet, the customer of forward Ijarah is liable for liquidated damages and is unable to receive a refund. It is understandable that the bank needs to protect itself in the event of default but such banking practice goes against the very nature of forward Ijarah. In this light, the forward Ijarah offered by KFHMB is not suitable for homebuyers. It is essential to enhance financial consumer protection and at the same time recognise that consumer rights come with consumer responsibilities (OECD, 2011). Homebuyers should not be held responsible and penalised if the housing project is abandoned by the builder because it is beyond their control.

There is certainly a need to devise home financing products that suit the financial needs of the consumer and at the same time conform fully to Shariah principles. In Malaysia, finance products such as BBA and MM are criticised by scholars because they deviate from Islamic teaching. This paper shows that there are various issues with regard to legal documentation and consumer protection in the event of project abandonment. Further studies are needed to investigate the subject matter in depth. This study reviewed the current offering of forward Ijarah in one bank, which could be extended further. Future research could compare the use of forward Ijarah in different countries.

\section{References}

1. Abu Ghuddah, A. S. (2007), "Practical Application of al-Ijarah al-Mawsufah fi alDhimmah (Forward Ijarah)", In 28th Al-Baraka Symposium on Islamic Economics. Jeddah: Al Baraka Banking Group.

International Journal of Management and Applied Research, 2019, Vol. 6, No. 4 
2. Amin, H.; Abdul-Rahman, A. and Abdul-Razak, D. (2016), "Malaysian consumers' willingness to choose Islamic mortgage products: An extension of the theory of interpersonal behaviour", International Journal of Bank Marketing, Vol. 34 Issue: 6, pp.868-884, https://doi.org/10.1108/IJBM-06-2015-0099

3. Ariff, M. and Rosly, S.A. (2011), "Islamic banking in Malaysia: Unchartered waters", Asian Economic Policy Review, Vol. 6, No. 2, pp. 301-319. https://doi.org/10.1111/j.1748-3131.2011.01208.x

4. Asian Institute of Finance (2013), Musharakah Mutanaqisah Home Financing, [Online] available from: http://www.aif.org.my/clients/aif_d01/assets/multimediaMS/publication/CaseStudy_ Musharakah.pdf [accessed on 20 July 2016].

5. Bank Negara Malaysia (2009), Draft of Shariah Parameter Reference 2: Ijarah Contract, Kuala Lumpur: Bank Negara Malaysia.

6. Global Islamic Finance Report (2016), Islamic Project Finance: A Growing Trend, [Online] Available from: http://www.gifr.net/gifr2016/ch_08.pdf [Accessed on 12 March 2018].

7. Hui, H. (2011), "Cycles in landed and non-landed housing sub-markets in Malaysia", International Journal of Housing Markets and Analysis, Vol. 4, No. 2, pp. 144-154, https://doi.org/10.1108/17538271111137921

8. Kashi, A. and Mohamad, A. (2017), "Does Musharakah Mutanaqisah converge with Bai Bithamin Ajil and conventional loans?", International Journal of Law and Management, Vol. 59, No. 5, pp.740-755, https://doi.org/10.1108/IJLMA-04-20160044

9. Kuwait Finance House Malaysia Berhad (2019), Product Disclosure Sheet, [Online] Available from: https://www.kfh.com.my/dam/jcr:bbf3f1b9-1dfe-469c-aebe5bf7ac082a90/PDS-\%20Ijarah\%20Mausufah\%20Fi\%20Zimmah\%20130519.pdf [accessed on 4 June 2019].

10. Lahsasna, A. (2018), Forward Lease Sukuk in Islamic Capital Markets, Cham: Palgrave Macmillan, https://doi.org/10.1007/978-3-319-94262-9

11. Monawer, M. A. T. and Aziz, A. A. (2015), "Dispute Over the Legality of Al-Ijarah Al-Mawsufah Fi Al-Dhimmah: A Survey of Fiqhi Opinions", ISRA International Journal of Islamic Finance, Vol. 7, No. 1, pp. 49-74.

12. National Housing Department Malaysia (2001), Towards successful housing development in Malaysia [Online] Available from:

http://ehome.kpkt.gov.my/index.php/pages/view/229 [accessed on 4 March 2019].

13. Neate, R. (2016), "HSBC fined $\$ 470 \mathrm{~m}$ for 'abusive mortgage practices' during 2008 crisis", The Guardian, [Online] Available from:https://www.theguardian.com/business/2016/feb/05/hsbc-fined-morgagepractices-financial-crisis [accessed on 4 March 2019].

International Journal of Management and Applied Research, 2019, Vol. 6, No. 4 
14. OECD (2011), G20 High-level Principles on Financial Consumer Protection, [Online] Available from: https://www.oecd.org/daf/fin/financial-markets/48892010.pdf [accessed on 4 March 2019].

15. Quah, H. W. (2019), Malaysia Industry Focus: Malaysia Property, DBS [Online] Available from: https://www.dbs.com/aics/pdfController.page?pdfpath=/content/article/pdf/AIO/0120 19/190104_insights_all_eyes_on_destocking_inititiative.pdf [accessed on 6 April 2019].

16. Shariah Advisory Council (2010), Shariah Resolutions in Islamic Finance, $2^{\text {nd }}$ ed., Malaysia: Shariah Advisory Council.

17. Subky, K.H.M., Liu, J.Y., Muhammad Muzzammil, M.M., Mokhtar, Z.F. and Faizrakhman, A. (2017), "The implication of Musharakah Mutanaqisah in Malaysian Islamic banking arena: a perspective on legal documentation", International Journal of Management and Applied Research, Vol. 4 No. 1, pp. 17-30. https://doi.org/10.18646/2056.41.17-003

18. The Sun Daily (2017), "One-third of recent abandoned housing projects in Selangor", The Sun Daily [Online] available from: https://www.thesundaily.my/archive/2173617-MTARCH429674 [accessed on 6 April 2019].

19. World Bank Group (2017), Mobilizing Islamic Finance for Infrastructure PublicPrivate Partnerships [Online] Available from: https://ppiaf.org/documents/5369/download [Accessed on 12 March 2019].

20. Wei, K. L. K. and Thaker, H. M. T. (2017), "A qualitative inquiry into Islamic home financing: evidence from Malaysia", Qualitative Research in Financial Markets, Vol. 9, No. 2, pp.147-167, https://doi.org/10.1108/QRFM-07-2016-0020

21. Yap, J. B. H. and Ng, X. H. (2018), "Housing affordability in Malaysia: perception, price range, influencing factors and policies", International Journal of Housing Markets and Analysis, Vol. 11, No. 3, pp.476-497, https://doi.org/10.1108/IJHMA08-2017-0069

22. Yusoff, S. S. M. and Oseni, U. A. (2019), "Standardisation of legal documentation in Islamic home financing in Malaysia: A literature survey", Journal of Islamic Accounting and Business Research, Vol. 10, No. 3, pp.448-465, https://doi.org/10.1108/JIABR-02-2017-0016

23. Zabri, M. Z. M. and Haron, R. (2019), “A comparative analysis of financial affordability in Islamic home financing instruments in Malaysia", International Journal of Housing Markets and Analysis, Vol. 12 No. 6, pp. 1093-1112, https://doi.org/10.1108/IJHMA-11-2018-0090

International Journal of Management and Applied Research, 2019, Vol. 6, No. 4 